\title{
Retraction: Molecular characterization of Legionella pneumophila-induced interleukin-8 expression in T cells
}

\author{
Reika Takamatsu', Hiromitsu Teruya ${ }^{1,2}$, Eriko Takeshima ${ }^{1,2}$, Chie Ishikawa ${ }^{1,3}$, Kunihiro Matsumoto $^{4}$, \\ Naofumi Mukaida ${ }^{5}$, Jian-Dong Li ${ }^{6}$, Klaus Heuner ${ }^{7}$, Futoshi Higa ${ }^{2}$, Jiro Fujita ${ }^{2}$ and Naoki Mori ${ }^{{ }^{*}}$
}

\section{Abstract \\ Article Retracted}

\section{Retraction}

After lengthy investigation by the editors, the original article [1] has been retracted because of inappropriate duplication of images from previously published articles. The last author, Naoki Mori takes full responsibility and apologizes for any inconvenience caused.

\begin{abstract}
Author details
'Division of Molecular Virology and Oncology, Graduate School of Medicine, University of the Ryukyus, 207 Uehara, Nishihara, Okinawa 903-0215, Japan. 2Division of Control and Prevention of Infectious Diseases, Graduate School of Medicine, University of the Ryukyus, 207 Uehara, Nishihara, Okinawa 9030215, Japan. ${ }^{3}$ Transdisciplinary Research Organization for Subtropics and Island Studies, University of the Ryukyus, 1 Senbaru, Nishihara, Okinawa 9030215, Japan. ${ }^{4}$ Department of Molecular Biology, Graduate School of Science, Nagoya University, Chikusa-ku, Nagoya 464-8602, Japan. ${ }^{5}$ Division of Molecular Bioregulation, Cancer Research Institute, Kanazawa University, 13-1 Takara-machi, Kanazawa 920-0934, Japan. ${ }^{6}$ Department of Microbiology and Immunology, University of Rochester Medical Center, 601 Elmwood Avenue, Rochester, New York 14642, USA. 'Project group 26 "Nosocomial Infections of the Elderly", Robert Koch-Institut, 20 Nordufer, Berlin 13353, Germany.
\end{abstract}

Received: 27 January 2011 Accepted: 2 June 2011

Published: 2 June 2011

\section{Reference}

1. Takamatsu R, Teruya H, Takeshima E, Ishikawa C, Matsumoto K, Mukaida N, Li J-D, Heuner K, Higa F, Fujita J, Mori N: Molecular characterization of Legionella pneumophila-induced interleukin-8 expression in T cells. BMC Microbiol 2010, 10:1

doi:10.1186/1471-2180-11-127

Cite this article as: Takamatsu et al:: Retraction: Molecular

characterization of Legionella pneumophila-induced interleukin-8 expression in T cells. BMC Microbiology 2011 11:127.

* Correspondence: n-mori@med.u-ryukyu.ac.jp

'Division of Molecular Virology and Oncology, Graduate School of Medicine, University of the Ryukyus, 207 Uehara, Nishihara, Okinawa 903-0215, Japan Full list of author information is available at the end of the article

Submit your next manuscript to BioMed Central and take full advantage of:

- Convenient online submission

- Thorough peer review

- No space constraints or color figure charges

- Immediate publication on acceptance

- Inclusion in PubMed, CAS, Scopus and Google Scholar

- Research which is freely available for redistribution

Submit your manuscript at www.biomedcentral.com/submit
( Biomed Central 